\title{
OPTIMIZATION OF ENZYMATIC HYDROLYSIS CONDITIONS OF SEAWEED (Gracilaria fisheri) PROTEIN BY USING ALCALASE® TO OBTAIN MAXIMUM ANGIOTENSIN-I-CONVERTING ENZYME (ACE) INHIBITORY ACTIVITY
}

\author{
AMIZA MAT AMIN*, WONG SHER LEE and KAZI NAZIRA SHARMIN \\ Faculty of Fisheries and Food Science, Universiti Malaysia Terengganu (UMT) \\ 21030 Kuala Nerus, Terengganu, Malaysia \\ *E-mail:ama@umt.edu.my
}

Accepted 11 July 2020, Published online 31 December 2020

\begin{abstract}
This study aimed to optimize the enzymatic hydrolysis conditions of Gracilaria fisheri protein by using Alcalase ${ }^{\circledR}$ to obtain maximum angiotensin-I-converting enzyme (ACE) inhibitory activity. Firstly, the seaweed protein was extracted using cellulase, sonication, and ammonium sulphate treatment, before dialysis and lyophilization. The yield of lyophilized seaweed protein extract was $8.75 \%$ with a protein content of $66.4 \%$. An optimization study for protein hydrolysis condition was performed by employing a three-level face-centered central composite design (CCD) using Design-Expert software. Four parameters used were $\mathrm{pH}(6.5-8.5)$, temperature $\left(50-60^{\circ} \mathrm{C}\right)$, hydrolysis time $(60-180 \mathrm{~min})$, and Alcalase ${ }^{\circledR}$ to substrate ratio $(\mathrm{E} / \mathrm{S})$ $(1.25-2.50 \%)$. Thirty runs of protein hydrolysis conditions with 6 center points were employed. The supernatant of the resulting protein hydrolysates was then lyophilized and analyzed for ACE inhibitory activity. This study found that the quadratic model could be used to explain the relationship between hydrolysis conditions of G. fisheri protein and ACE inhibitory activity. The optimum condition to obtain maximum ACE inhibitory activity was at $\mathrm{pH}$ of 7.5 , the temperature of $54.6^{\circ} \mathrm{C}$, hydrolysis time of $175 \mathrm{~min}$, and $\mathrm{E} / \mathrm{S}$ of $1.47 \%$. The half-maximal inhibitory concentration $\left(\mathrm{IC}_{50}\right)$ of the seaweed protein hydrolysate at optimum condition was $2.97 \pm 0.37 \mathrm{mg} / \mathrm{mL}$.
\end{abstract}

Key words: Gracilaria fisheri, angiotensin-I-converting enzyme (ACE), Alcalase ${ }^{\circledR}$, protein hydrolysis

\section{INTRODUCTION}

Hypertension, a high blood pressure condition is a major modifiable risk factor for cardiovascular diseases such as stroke, heart failure, chronic kidney disease, and premature death (Kjeldsen, 2018; Seca, 2018). The angiotensin-I-converting enzyme (ACE) is a substance that alters the regulation of blood pressure. ACE promotes the conversion of angiotensin-I to the potent vasoconstrictor angiotensin-II, inactivates the vasodilator bradykinin, and gives depressor action in the renin-angiotensin system that lead to the increase of blood pressure (Wijesekara \& Kim, 2010).

Synthetic ACE inhibitor drugs such as benazepril, captopril, and enalapril are used to treat hypertension (Iwaniak et al., 2014; Daskaya-dikmen et al., 2017). Previous studies have shown that

* To whom correspondence should be addressed. synthetic drugs not only have outstanding effects on antihypertensive activity in clinical treatments but also give some side-effects such as cough, rashes, and vasodilatory edema (Messerli, 2002; Qu et al., 2010; Iwaniak et al., 2014). Besides, the drugs may contain carcinogenic contaminants known as N-nitrosodimethylamine (NDMA) (Shanley, 2018). Thus, natural ACE inhibitor peptides from food protein may offer a better and safer alternative to synthetic drugs. Several foods such as soybean (Guang \& Phillips, 2009), Porphyra yezeonsis seaweed (Qu et al., 2010), spinach (Daskaya-dikmen et al., 2017) were investigated for their potential ACE inhibitor activities by using in vitro or in vivo assays (Daskaya-dikmen et al., 2017).

Protein hydrolysis is a process of cleaving peptide bonds in protein using an enzyme, alkaline, or acid. Enzymatic protein hydrolysis using protease at a controlled condition ( $\mathrm{pH}$, temperature, enzyme to substrate ratio, hydrolysis time) are commonly 
used to modify the functional properties and nutritional value of protein foods as well as to generate bioactive peptides (Vijaykrishnaraj \& Prabhasankar, 2015; Hayes, 2018). Bioactive peptides are defined as peptide sequences within a protein that exerts a beneficial effect on body functions and/or positively impact human health, beyond its known nutritional value (Kitts \& Weiler, 2003). These peptides can regulate important bodily functions through their myriad of activities, including antihypertensive, antimicrobial, antithrombotic, immunomodulatory, opioid, antioxidant, and mineral binding functions (Kim et al., 2007; Yokoyama et al., 2009; Venugopal, 2009; Rutherford-Markwick, 2012; Rodan et al., 2017; Sánchez \& Vázquez, 2017).

Seaweeds or known as macroalgae are members of the algal group. Despite the high protein content (up to $47 \%$ ) and complete essential amino acid profile in some species, their protein fraction is still relatively underexplored. Besides potential as alternative protein sources, macroalgae can also provide bioactive peptides and other proteinaceous compounds with biological value. Many studies have been reported on the enzymatic hydrolysis of seaweed to generate bioactive peptides including from Palmaria palmata (Harnedy \& FitzGerald, 2013; Beaulieu et al., 2016) and Fucus spiralis (Paiva et al., 2017), Chlorella ellipsoidea (Ko et al., 2012a) and Porphyra columbina (Cien et al., 2015). However, only one study has been reported on the optimization of enzymatic protein hydrolysis of red seaweed (Porphyra yezoensis) using Alcalase ${ }^{\circledR}$ to obtain maximum ACE inhibitory activities $(\mathrm{Qu}$ et al., 2010).

Gracilaria fisheri is a major cultivated seaweed in Thailand and it has the potential to be used as a protein substrate to prepare ACE inhibitor peptides. To date, only several studies have been reported on $G$. fisheri which are its nutritional composition (Lawanyawut et al., 2002; Benjama \& Masniyom, 2012; Setthamongkol et al. (2015), its seafood-like flavor obtained from the enzymatic hydrolysis of protein by-product using bromelain enzyme (Laohakunjit et al., 2014), its biochemical characteristics and antioxidant activity of crude and purified sulfated polysaccharides (Imjongjairak et al., 2015), patterns of element concentrations and heavy metal accumulations in edible seaweed on the heavy metal profiles (Nguyen et al., 2018) and the application of its protein extract to prevent acute hepatopancreatic necrosis disease (AHPND) infection in shrimp (Boonsri et al., 2016). However, until now, no study has been reported on the generation of bioactive peptides from $G$. fisheri protein. Thus, this study was aimed to optimize the enzymatic protein hydrolysis condition of $G$. fisheri protein to obtain maximum ACE inhibitory activity.

\section{MATERIALS AND METHODS}

Five kilograms of dried seaweed (Gracilaria fisheri) were purchased from a supplier in Pattani, Thailand. The seaweed was stored in the chiller at $4{ }^{\circ} \mathrm{C}$ until further use. The commercial food-grade enzyme, Alcalase ${ }^{\circledR}$, angiotensin-I-converting enzyme (ACE), cellulase from Aspergillus niger, and Hipurry-Lhistidyl-L-leucine (HHL) were purchased from Sigma-Aldrich (M) Sdn. Bhd. Other chemicals used were of analytical grades.

\section{Sample preparation}

Dried seaweed was washed with tap water three times to remove all the unwanted impurities, adhering to sand particles, epiphytes, and other contaminants (Chan \& Matanjun, 2017). Next, the seaweed was cut into small pieces of $1 \mathrm{~cm}$ long. Then, the excess water was removed by placing the wet seaweed in a strainer, and then the seaweed was frozen and freeze-dried (FreeZone 4.5 L benchtop freeze dry system, Labconco, USA). Finally, the lyophilized seaweed was ground into powder form using a dry grinder and stored in a chiller until further use.

\section{Extraction of seaweed protein}

Extraction of seaweed protein was employed as described by Galland-Irmouli et al. (1999) with slight modification. A combination of treatments using cellulase enzyme, sonication, and ammonium sulphate extraction was used. Ten grams of lyophilized seaweed powder was suspended in 250 $\mathrm{mL}$ acetate buffer with $1 \mathrm{~g}$ cellulase for $2 \mathrm{hr}$ by using a water bath (Shaker bath 903, Protech, UK). Next, the mixture was added with $1 \mathrm{~L}$ of ultrapure water, followed by sonication for $1 \mathrm{hr}$. Then, the seaweed solution was stirred overnight on a magnetic stirrer plate at $4^{\circ} \mathrm{C}$. The seaweed solution was centrifuged at $10,000 \times g$ for $30 \mathrm{~min}$ and the supernatant was decanted. The supernatant was brought to $60 \%$ $(\mathrm{w} / \mathrm{v})$ ammonium sulphate saturation. The mixture was stirred at $4^{\circ} \mathrm{C}$ for $1 \mathrm{hr}$, followed by centrifugation at $10,000 \times \mathrm{g}$ for $30 \mathrm{~min}$ to precipitate the protein fraction. The precipitate was dialyzed using $3.5 \mathrm{kDa}$ MWCO dialysis tubing (Fischer Scientific, USA) against ultrapure water at $4^{\circ} \mathrm{C}$ overnight. Finally, the precipitate was freeze-dried (FreeZone 4.5 L benchtop freeze dry system, Labconco, USA) and stored at $-80^{\circ} \mathrm{C}$ until further use. 
Determination of yield and protein content of lyophilized seaweed protein extract

The yield (in triplicate) of seaweed protein extract powder obtained from lyophilized seaweed powder was calculated as follows:

Seaweed protein extract powder $(\%)=$

Weight of seaweed protein extra powder

Weight of freeze - dried seaweed powder

Determination of protein content was carried out using the Kjeldahl method according to AOAC (2000). A conversion factor of nitrogen to the protein of 5.0 was used (Angell, 2016).

Optimization of enzymatic protein hydrolysis to obtain maximum ACE inhibitory activity

A faced-centered Central Composite Design (CCD) was employed in the optimization study by using Response Surface Methodology (RSM). Thirty experimental runs with six center points were generated by Design Expert 12.0.1.0 software (StatEase Inc., 2019). Four experimental parameters ( $\mathrm{pH}$, temperature, hydrolysis time, and $\mathrm{E} / \mathrm{S}$ ) and three levels $(-1,0,+1)$ for each parameter were used in this study. The experimental range and values of independent variables which include $\mathrm{pH}$, temperature, hydrolysis time, and E/S with three levels are as shown in Table 1. The ranges of experimental factors were set according to previous

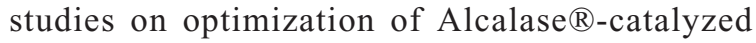
protein hydrolysis (Normah et al., 2005; Amiza et al., 2017).

Before preparation of seaweed protein hydrolysates, a series of calculations were performed to determine the mass of raw material, enzyme, and water in each run of protein hydrolysis of seaweed.

Calculation of mass of raw material, enzyme, and water for enzymatic protein hydrolysis of seaweed

The calculations were carried out according to Kristinsson and Rasco (2000). a. Mass of protein (usually fixed at less than 10\%)

$$
\mathrm{MP}=\mathrm{M} \times \frac{\mathrm{S}(\%)}{100}
$$

Where,

MP $=$ Mass of protein $(\mathrm{g})$

$\mathrm{M}=$ Total mass of total reaction mixtures $(\mathrm{g})=10 \mathrm{~g}$

$\mathrm{S}(\%)=$ substrate concentration (protein concentration) $(\% \mathrm{w} / \mathrm{w})$

$$
=[(66.4 / 100) \times 10] / 100 \times 100 \%=6.64 \%
$$

$$
\text { Thus, MP }=10 \times \frac{6.64 \%}{100}=0.664 \mathrm{~g}
$$

b. Mass of raw material

$$
\mathrm{MR}=1.1 \times \mathrm{MP} \times\left(\frac{100}{\% \text { protein }}\right)
$$

Where,

$\mathrm{MR}=$ Mass of raw material $(\mathrm{g})$

$\mathrm{PR}(\%)=$ Percentage of protein in seaweed

$$
\text { Thus, MR }=1.1 \times 0.664 \times\left(\frac{100}{66.4}\right)=1.10 \mathrm{~g}
$$

c. Mass of water

$$
\mathrm{MW}=1.1 \times\left(\mathrm{M}-\mathrm{M}_{\mathrm{enz}}\right)-\mathrm{MR}
$$

Where,

$\mathrm{MW}=$ Mass of water $(\mathrm{g})$

$\mathrm{M}_{\mathrm{enz}}=$ Mass of enzyme solution $(\mathrm{g})$

$$
\text { Thus, } \mathrm{MW}=1.1 \times(10-2)-1.1=7.7 \mathrm{~g}
$$

This means that a total of $7.7 \mathrm{~g}$ of water was needed for each protein hydrolysis run, including the mass of acid or alkali used for $\mathrm{pH}$ adjustment.

Table 1. Experimental range and values of independent variables at three equidistant levels

\begin{tabular}{lcccc}
\hline \multirow{2}{*}{ Independent variables } & Symbol & \multicolumn{3}{c}{ Range and levels } \\
\cline { 3 - 5 } & & -1 & 0 & +1 \\
\hline $\mathrm{pH}$ & $\mathrm{A}$ & 6.5 & 7.5 & 8.5 \\
Temperature $\left({ }^{\circ} \mathrm{C}\right)$ & $\mathrm{B}$ & 50 & 55 & 60 \\
Hydrolysis time $(\mathrm{min})$ & $\mathrm{C}$ & 60 & 120 & 180 \\
Enzyme to substrate ratio $(\mathrm{E} / \mathrm{S}, \% \mathrm{w} / \mathrm{w})$ & $\mathrm{D}$ & 1.25 & 1.75 & 2.25 \\
\hline
\end{tabular}


d. Mass of enzyme (Alcalase $\left.{ }^{\circledR}\right)$

$$
\mathrm{ME}=\left(\frac{\mathrm{ES}(\%)}{100}\right) \times \mathrm{MP}
$$

Where,

$\mathrm{ME}=$ Mass of enzyme

$\mathrm{ES}(\%)=$ enzyme to substrate ratio

For $1.25 \% \mathrm{E} / \mathrm{S}$ :

Thus, $\mathrm{ME}=\left(\frac{1.25}{100}\right) \times 0.664=0.0083 \mathrm{~g}$

(diluted with distilled water to $1 \mathrm{~g}$ )

\section{Preparation of seaweed protein hydrolysate}

The preparation of seaweed protein hydrolysate was performed as described by Amiza et al. (2017). Firstly, $1.10 \mathrm{~g}$ of seaweed protein extract was homogenized with $4 \mathrm{~g}$ of distilled water using a homogenizer. Secondly, the homogenate was heated at $85^{\circ} \mathrm{C}$ for $20 \mathrm{~min}$ in a water bath (TE-10D Temp., Techne, UK) to inhibit the enzymatic activity in the seaweed. Each run of seaweed protein hydrolysis used $7.7 \mathrm{~g}$ of water, whereby the mass of $\mathrm{NaOH}$ used for $\mathrm{pH}$ adjustment was included in it as well. Adjustment of $\mathrm{pH}$ was carried out for the respective enzyme by using $1.0 \mathrm{M} \mathrm{NaOH}$ and $1.0 \mathrm{M} \mathrm{HCl} . \mathrm{pH}$ was measured using a pH meter (InoLab pH 720, Wissenschaftlich-Techische Werkstatten GmbH, Germany). Then, the homogenized seaweed protein was cooled down before conducting the enzymatic protein hydrolysis as recommended by Ko et al. (2012b).

The seaweed protein homogenate was heated at the desired temperature (Table 1) in a water bath shaker (shaker Bath 903, Protech, UK). Then, once the desired temperature was reached, $1 \mathrm{~g}$ of enzyme solution (for example, to prepare $1.25 \% \mathrm{E} / \mathrm{S}$, $0.0083 \mathrm{~g}$ Alcalase ${ }^{\circledR}$ was diluted to $1 \mathrm{~g}$ with distilled water) was added into the homogenate and the hydrolysis time was started. After the enzymatic hydrolysis process was completed, the seaweed protein hydrolysate was heated at $85^{\circ} \mathrm{C}$ for $20 \mathrm{~min}$ in a water bath to inactivate the enzyme activity. Next, the protein hydrolysate was cooled down for a while, followed by centrifugation at $10000 \mathrm{rpm}$ for $10 \mathrm{~min}$ at $4{ }^{\circ} \mathrm{C}$. The resulting supernatant was collected and frozen, before freeze-drying (FreeZone 4.5 L benchtop freeze dry system, Labconco, USA). The lyophilized seaweed hydrolysate was ground into powder form by using a grinder and kept in a chiller $\left(4^{\circ} \mathrm{C}\right)$ in an airtight container for further $\mathrm{ACE}$ inhibitory activity assay.

\section{Determination of $\mathrm{ACE}$ inhibitory activity}

Determination of ACE inhibitory activity was carried out using the spectrophotometric method according to Cushman and Cheung (1971). It was based on the hydrolysis of hippuryl-I-histidyl-Lleucine (HHL) by ACE to histidyl-leucine (HL) and hippuric acid (HA). This method was carried out through several steps including extraction of HA with ethyl acetate, evaporation, redissolution in water, and measurement of absorbance of hippuric acid at $228 \mathrm{~nm}$ using a spectrophotometer.

Seaweed hydrolysate $(50 \mu \mathrm{L} ; 1 \mathrm{mg} / \mathrm{mL}$ dissolved in $0.1 \mathrm{M}$ sodium borate buffer containing $0.3 \mathrm{M}$ $\mathrm{NaCl}$ at $\mathrm{pH} 8.3$ ) was pre-incubated with $50 \mu \mathrm{L}$ of ACE solution $(2 \mathrm{mU} / \mathrm{mL})$ at $37^{\circ} \mathrm{C}$ for $10 \mathrm{~min}$ using a water bath (Shaker bath 903, Protech, UK). Then $150 \mu \mathrm{L}$ of the substrate $(2.17 \mathrm{mM}$ HHL in $0.1 \mathrm{M}$ sodium borate buffer containing $0.3 \mathrm{M} \mathrm{NaCl}$ at $\mathrm{pH}$ 8.3) was added into the hydrolysate, followed by incubation at $37^{\circ} \mathrm{C}$ for $30 \mathrm{~min}$. Then, the reaction was terminated by adding $250 \mu \mathrm{L}$ of $1 \mathrm{M} \mathrm{HCl}$.

Extraction of HA was carried out using $500 \mu \mathrm{L}$ of ethyl acetate. An aliquot of $200 \mu \mathrm{L}$ of the extract was evaporated in an oven dryer (UNB 400, Memmert, Germany) at $80^{\circ} \mathrm{C}$ for 30 min until completely dry. Then, the residue was dissolved in $1 \mathrm{~mL}$ of distilled water and the absorbance was measured at $288 \mathrm{~nm}$ using a UV-VIS spectrophotometer (Gary 50 Probe, Varian Inc., US). The ACE inhibitory activity was calculated by using the following formula:

$$
\text { ACE Inhibition }(\%)=\frac{A_{c}-A_{s}}{A_{c}-A_{b}} \times 100 \%
$$

Where,

$\mathrm{A}_{\mathrm{c}}=$ Absorbance of control sample (HHL $+10 \mu \mathrm{L}$ buffer + ACE)

$\mathrm{A}_{\mathrm{s}}=$ Absorbance of sample solution (HHL $+10 \mu \mathrm{L}$ sample + ACE)

$\mathrm{A}_{\mathrm{b}}=$ Absorbance of blank solution (HHL $+20 \mu \mathrm{L}$ buffer)

The present optimization study resulted in $30 \mathrm{ACE}$ inhibitory data for the respective enzymatic protein hydrolysis conditions, which were analyzed using Design Expert 12.0.1.0 software (StatEase Inc., 2019). Design-Expert software suggested the model explain the relationship between the enzymatic protein hydrolysis condition and ACE inhibitor activity, the sequential model sum of squares, ANOVA table, final equation, and recommended solutions for optimization (Zaliha et al., 2017).

\section{Validation of optimum condition}

The optimum condition was suggested by Design-Expert software after the analysis of the optimization study. The value of ACE inhibitory activity at predicted optimum condition was known as "predicted value". Validation was performed to 
check the validity of the predicted model. The suggested optimum condition chosen was $\mathrm{pH}$ of 7.5 , the temperature of $54.6^{\circ} \mathrm{C}$, hydrolysis time of 175 min, and enzyme to substrate ratio of $1.47 \%$. Four replicates of enzymatic protein hydrolysis of seaweed protein extract were carried out at this suggested optimum condition. The supernatants of the resulting hydrolysates were lyophilized and their ACE inhibitory activity was analyzed. One sample t-test was conducted to compare the predicted ACE inhibitory activity value from RSM with the ACE inhibitory activity value from the experiment.

\section{Half maximal inhibitory concentration $\left(\mathrm{IC}_{50}\right)$ of seaweed hydrolysate prepared under optimum condition}

Half maximal inhibitory concentration $\left(\mathrm{IC}_{50}\right)$ is defined as the concentration of inhibitor to inactivate $50 \%$ of the activity of ACE (Lee et al., 2010). A serial dilution of seaweed protein hydrolysate $(2,4,6,8,10 \mathrm{mg} / \mathrm{mL})$ prepared at optimum condition was used. Then, the seaweed protein hydrolysate was used to determine the $\mathrm{IC}_{50}$. A plot of ACE inhibitory activity against the concentration of seaweed hydrolysate was plotted to obtain the $\mathrm{IC}_{50}$ value.

\section{Statistical analysis}

All data were presented in form of average \pm standard deviation, while the confidence level was set at $95 \%$, except for the optimization study.

\section{RESULTS AND DISCUSSION}

\section{Yield and protein content of seaweed protein extract}

Table 2 shows the yield and crude protein content for lyophilized seaweed powder and lyophilized seaweed protein extract powder. Only $16 \%$ of lyophilized seaweed powder was obtained from the cleaned seaweed, with $10.56 \%$ protein content.

The protein content of seaweed powder from Gracilaria fisheri was in a similar range with most Gracilaria sp. which was reported between $7 \%$ and
13\% (Briggs \& Smith, 1993) as well as with green, brown, and red seaweed from Persian Gulf of Iran ( $10 \%$ to $30 \%$ ) (Rohani-Ghadikolaei et al., 2012). It was also comparable with the other red seaweeds such as Palmaria palmata (13\%) (Galland-Irmouli et al., 1999), but contained lower protein content as compared to Mastocarpus stellatus (25.4\%) and Polysiphonia spp. (31.8\%) (Venugopal, 2008).

A combination of treatments i.e. cellulase, sonication, and ammonium sulphate was used for protein extraction from $G$. fisheri. Cellulase enzyme was used to break down the cellulose in the cell wall into monosaccharides (Fleurence et al., 1995). Ultrasound caused rarefactions and compression occur that lead to the cell wall collapse (Kadam et al., 2017). High agitation force generated by constant circular motion that softens the cell wall to facilitate the process of cell wall's breakdown (Harnedy \& FitzGerald, 2013a). Ammonium sulphate can increase the solubility of globular protein through the salting-in process. The solubility of protein tends to decrease at higher ammonium sulphate concentrations and thus lead to precipitation of protein (Voet et al., 2018). According to Table 2, the yield of lyophilized protein extract from lyophilized $G$. fisheri powder was $8.75 \%$ with a crude protein content of $66.4 \%$. Using a $\mathrm{pH}$-shift method, higher yields were obtained for $P$.

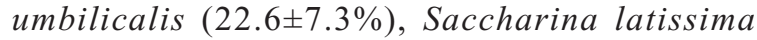
$(25.1 \pm 0.9 \%)$, and Ulva lactuca $(19.6 \pm 0.8 \%)$ as reported by Harrysson et al. (2018). The seaweed protein extract yield in this study was higher than those of Ulva lactuca (19\%) and S. latissimi (10.1\%) (Harrysson et al., 2018). The protein content of $G$. fisheri protein extract was lower compared to Porphyra sp. (73.47 $\pm 1.65 \%)$ (Admassu et al., 2018) and P. umbilicalis (70.1\%) (Harrysson et al., 2018). However, the protein concentration in the present study was higher than U. lactuca $(51.2 \pm 2.1 \%)$ and S. latissima $(40.7 \pm 0.5 \%)$ protein extract (Harrysson et al., 2018).

The differences in the yield and protein content of different seaweed species could be due to the differences in structure, morphology, and chemical composition of the seaweed protein (Barbarino \& Lourenço, 2005). Among the seaweed, red seaweed has been reported to contain higher protein content

Table 2. Yield and protein content of lyophilized seaweed powder and lyophilized seaweed protein extract $(n=3)$

\begin{tabular}{lcc}
\hline Sample & Yield (\%) & Crude protein content (\%) \\
\hline Lyophilized seaweed powder & ${ }^{*} 16.00$ & $10.53 \pm 0.36$ \\
Lyophilized seaweed protein extract powder & ${ }^{* *} 8.75$ & $66.40 \pm 0.35$ \\
\hline
\end{tabular}

${ }^{*}$ Yield per $100 \mathrm{~g}$ of cleaned seaweed.

**Yield per $100 \mathrm{~g}$ of lyophilized seaweed powder. 
compared to green and brown seaweed (Fleurence, 1999). It is noteworthy that the protein content of seaweeds varies not only between species but also among seasonal periods (Mishra et al., 1993). The efficiency of cell wall disruption methods also affected the yield and protein content of the extract. Among the commonly used extraction method were enzyme lysis (Fleurence et al., 1995), ultrasonic bath (Kadam et al., 2017), high shear force (Harnedy \& FitzGerald, 2013a), and pH-shift (Harrysson et al., 2018). However, according to Wijesinghe and Jeon (2012), extraction of seaweed protein is often hindered by a high degree of structural complexity, rigidity, and assemblies of macromolecular algal cell-wall polysaccharides cross-linked through disulfide bonds.

Optimization of enzymatic protein hydrolysis condition to obtain the maximum ACE inhibitory activity from seaweed protein extract

Response Surface Methodology (RSM) was used to optimize the enzymatic protein hydrolysis of seaweed protein extract using Alcalase ${ }^{\circledR}$ to obtain maximum ACE inhibitory activity. RSM gave the optimum conditions to obtain the desired responses and explain the relationship between the experi- mental variables and their response (Amiza et al., 2011).

Before the optimization study was carried out, the experimental design of the optimization study was generated using Design Expert ${ }^{\circledR}$ Version 12.0.1.0 software (StatEase Inc., 2019). The software required experimental variables and response variables to be supplied for the optimization study. There were four experimental variables which were hydrolysis time, temperature, $\mathrm{pH}$, and enzyme to substrate ratio. Thirty experimental runs were generated randomly by RSM using face-centered Central Composite Design (CCD), while the response variable was ACE inhibitory activity.

\section{Data of optimization study}

Table 3 shows the data of ACE inhibitory activity obtained from 30 runs of enzymatic seaweed protein hydrolysis. The range of ACE inhibitory activity of seaweed protein hydrolysate was from $36.43 \%$ to $62.56 \%$. The highest ACE inhibitory activity was given by the hydrolysis condition at a $\mathrm{pH}$ of 7.5 , the temperature of $55^{\circ} \mathrm{C}$, hydrolysis time of $120 \mathrm{~min}$, and enzyme concentration (E/S) of $1.75 \%$. Whereas, the lowest ACE inhibitory activity was given by that of $\mathrm{pH}$ of 6.5 , the temperature of

Table 3. Experimental data of ACE inhibitory activity (\%) from seaweed protein hydrolysate using face-centered Central Composite Design (CCD)

\begin{tabular}{|c|c|c|c|c|c|c|}
\hline Std & Run & $\begin{array}{l}\text { Factor } 1 \\
\mathrm{~A}: \mathrm{pH}\end{array}$ & $\begin{array}{c}\text { Factor } 2 \\
\text { B: Temperature }\left({ }^{\circ} \mathrm{C}\right)\end{array}$ & $\begin{array}{c}\text { Factor } 3 \\
\text { C: Time (min) }\end{array}$ & $\begin{array}{c}\text { Factor } 4 \\
\text { D: E/S (\%) }\end{array}$ & $\begin{array}{c}\text { ACE inhibitory activity } \\
(\%)\end{array}$ \\
\hline 16 & 1 & 8.5 & 60 & 180 & 2.25 & 42.16 \\
\hline 21 & 2 & 7.5 & 55 & 60 & 1.75 & 60.20 \\
\hline 30 & 3 & 7.5 & 55 & 120 & 1.75 & 58.68 \\
\hline 22 & 4 & 7.5 & 55 & 180 & 1.75 & 59.02 \\
\hline 28 & 5 & 7.5 & 55 & 120 & 1.75 & 61.72 \\
\hline 7 & 6 & 6.5 & 60 & 180 & 1.25 & 44.69 \\
\hline 4 & 7 & 8.5 & 60 & 60 & 1.25 & 48.40 \\
\hline 6 & 8 & 8.5 & 50 & 180 & 1.25 & 48.57 \\
\hline 20 & 9 & 7.5 & 60 & 120 & 1.75 & 42.66 \\
\hline 5 & 10 & 6.5 & 50 & 180 & 1.25 & 49.58 \\
\hline 27 & 11 & 7.5 & 55 & 120 & 1.75 & 58.35 \\
\hline 18 & 12 & 8.5 & 55 & 120 & 1.75 & 55.99 \\
\hline 13 & 13 & 6.5 & 50 & 180 & 2.25 & 45.53 \\
\hline 8 & 14 & 8.5 & 60 & 180 & 1.25 & 47.39 \\
\hline 15 & 15 & 6.5 & 60 & 180 & 2.25 & 41.65 \\
\hline 3 & 16 & 6.5 & 60 & 60 & 1.25 & 38.79 \\
\hline 19 & 17 & 7.5 & 50 & 120 & 1.75 & 48.90 \\
\hline 24 & 18 & 7.5 & 55 & 120 & 2.25 & 61.05 \\
\hline 23 & 19 & 7.5 & 55 & 120 & 1.25 & 61.38 \\
\hline 14 & 20 & 8.5 & 50 & 180 & 2.25 & 42.33 \\
\hline 12 & 21 & 8.5 & 60 & 60 & 2.25 & 45.19 \\
\hline 9 & 22 & 6.5 & 50 & 60 & 2.25 & 41.15 \\
\hline 17 & 23 & 6.5 & 55 & 120 & 1.75 & 50.93 \\
\hline 2 & 24 & 8.5 & 50 & 60 & 1.25 & 46.88 \\
\hline 25 & 25 & 7.5 & 55 & 120 & 1.75 & 61.05 \\
\hline 10 & 26 & 8.5 & 50 & 60 & 2.25 & 43.34 \\
\hline 11 & 27 & 6.5 & 60 & 60 & 2.25 & 36.42 \\
\hline 1 & 28 & 6.5 & 50 & 60 & 1.25 & 40.81 \\
\hline 29 & 29 & 7.5 & 55 & 120 & 1.75 & 62.23 \\
\hline 26 & 30 & 7.5 & 55 & 120 & 1.75 & 62.56 \\
\hline
\end{tabular}


$60^{\circ} \mathrm{C}$, hydrolysis time of $60 \mathrm{~min}$, and enzyme concentration $(\mathrm{E} / \mathrm{S})$ of $2.25 \%$.

The range of ACE inhibitory activity in this study was comparable with marine green algae (Ulva intestinalis) (50.43\% to $63.91 \%)$ (Sun et al., 2019) and sardinella by-product (13.2\% to $63.2 \%)$ (NedjarArroume et al., 2008). However, the range of ACE inhibitory activity obtained in the present study was higher compared to Pacific hake (4.5\% to $43.3 \%$ ) (Cinq-Mars \& Li-Chan, 2007), but lower than whey protein $(22.4 \%$ to $73.45 \%$ ) (Guo et al., 2009), milk protein (22.4\% to $79.7 \%$ ) (Uluko et al., 2013), angel wing clam (54.6\% to $85.17 \%$ ) (Amiza et al., 2017), mud crab (58.01\% to $96.01 \%$ ) (Zaliha et al., 2017) and blood cockle (44.90\% to $98.02 \%$ ) (Aishah et al., 2017).

The difference in ACE inhibitory activity obtained might due to different types of protein sources (Paiva et al., 2016), different range of parameters used, and different types of enzymes employed during the enzymatic protein hydrolysis process (Qu et al., 2010).

By using model adequacy checking, the experimental data were further analyzed to test whether the fitted model can provide an adequate approximation to the true system. The experimental data were then analyzed in several aspects including coefficient design, variance, diagnostic case statistics, and response surface plots and effects of factors (Morshedi \& Akbarian, 2014).

\section{Model adequacy checking for ACE inhibitory activity of seaweed protein hydrolysate}

Design Expert ${ }^{\circledR}$ 12.0.1.0 software (Stat-Ease Inc., 2019) was used to analyze the prediction model for the ACE inhibitory activity, which was the response variable. The prediction model for the ACE inhibitory activity can be fitted into linear, twofactor interaction (2FI), cubic, or quadratic. Table 4 shows the suggested model for the ACE inhibitory activity of seaweed protein hydrolysate. The quadratic model equation was suggested as the best model as it gave low standard deviation, high Rsquared value, and low PRESS value.

The standard deviation is the statistical dispersion where the smaller value is preferred (Rodrigues et al., 2017). The lower the standard deviation value, the lower the standard error. Based on Table 4, the standard deviation for the selected model was 1.85 which was lower compared to other models of linear, 2FI model, and cubic.

R-Squared value can be used to measure the percentage of the total variation in the response variable that is accounted for by the manipulated variable for the model. Any R-squared value $<1$ indicated that at least some variability in the data cannot be employed for the model whereby a value that is closed to 1 is more desirable (Hamilton et al., 2015). The R-squared value was 0.9748 which indicated that $97.48 \%$ of the variability in the response on ACE inhibitory activity explained by the selected model (Table 4). In this study, the cubic model obtained the highest R-squared value, followed by the quadratic model. However, the cubic model was discarded because it was aliased and could not be selected in this study. Therefore, the quadratic model was chosen. The adjusted Rsquared value defines the variation of the R-squared value that reflects the number of factors in the model (Montgomery, 2001). Therefore, the R-squared value and the adjusted $\mathrm{R}$-squared value that close to each other are more preferable.

PRESS stands for Prediction Error Sum of Square which is a measurement of the goodness of the particular model to fit each design point and the smaller PRESS value is more preferable (Palmer \& Connell, 2009). In this study, the quadratic model possessed the lowest PRESS value among all stated models. This indicated that the quadratic model had the lowest residual error sum of squares. Thus, the quadratic model fitted the data well and can be chosen in this study. Also, previous studies carried out on whey (Van der Ven et al., 2002), rice dregs (He et al., 2005), wheat gluten (Dadzie et al., 2013), seaweed (Porphyra yezoensis) (Qu et al., 2010) used quadratic model for the optimization of ACE inhibitory activity.

\section{Analysis of variance (ANOVA) for ACE inhibitory activity}

The suggested model was analyzed through analysis of variance (ANOVA) statistically to illustrate which independent variable gave a significant effect on ACE inhibitory activity. By comparing the variations of treatment and random errors inherent to the measurement of the generated

Table 4. Model Summary Statistics of ACE inhibitory activity

\begin{tabular}{ccccccc}
\hline Source & Std. Dev. & $\mathrm{R}^{2}$ & Adjusted $\mathrm{R}^{2}$ & Predicted $\mathrm{R}^{2}$ & PRESS \\
\hline Linear & 8.72 & 0.0677 & -0.0814 & -0.2917 & 2633.5 & \\
2FI & 9.79 & 0.1075 & -0.3622 & -1.9671 & 6049.24 & Suggested \\
Quadratic & $\mathbf{1 . 8 5}$ & $\mathbf{0 . 9 7 4 8}$ & $\mathbf{0 . 9 5 1 3}$ & $\mathbf{0 . 9 1 8 4}$ & $\mathbf{1 6 6 . 0 6}$ & Aliased \\
Cubic & 1.99 & 0.9864 & 0.9436 & 0.2990 & 1426.59 & . \\
\hline
\end{tabular}


Table 5. ANOVA table for Response Surface Reduced Quadratic Model for ACE inhibitory activity

\begin{tabular}{lccccc}
\hline Source & Sum of Squares & df & Mean Square & F-value & p-value \\
\hline Model & 1972.38 & 9 & 219.15 & 66.16 & $<0.0001$ \\
A-pH & 52.36 & 1 & 52.36 & 15.81 & 0.0007 \\
B-Temperature & 21.65 & 1 & 21.65 & 6.53 & 0.0188 \\
C-Time & 21.65 & 1 & 21.65 & 6.53 & 0.0188 \\
D-E/S & 42.53 & 1 & 42.53 & 12.84 & 0.0019 \\
AB & 19.23 & 1 & 19.23 & 5.80 & 0.0257 \\
AC & 47.75 & 1 & 47.75 & 14.41 & 0.0011 \\
A & 82.97 & 1 & 82.97 & 25.05 & $<0.0001$ \\
B & 486.13 & 1 & 486.13 & 146.75 & $<0.0001$ \\
D & 15.66 & 1 & 15.66 & 4.73 & 0.0419 \\
Residual & 66.25 & 20 & 3.31 & & 1 \\
Lack of Fit & 49.71 & 15 & 3.31 & & 0.5482 \\
Pure Error & 16.54 & 5 & 3.31 & & not significant \\
Cor Total & 2038.64 & 29 & & & \\
\hline
\end{tabular}

responses, ANOVA was used to evaluate the quality of the model fitted (Larson, 2008). Then, the selected quadratic model for ACE inhibitory activity was further reduced to improve the model. To examine the fitted model to ensure adequate approximation is provided to the true system, a reduction needed to be done.

Table 5 shows the ANOVA table for the response surface reduced quadratic model for ACE inhibitory activity. F-value of 66.16 for the model illustrated that the model was significant (Table 5). There was only a $0.01 \%$ chance that F-value could occur due to noise. Also, the Prob $>$ F-value with less than 0.05 indicated that the model terms were significant. Hence, the model term of A, B, C, D, $\mathrm{AB}, \mathrm{AC}, \mathrm{A}^{2}, \mathrm{~B}^{2}, \mathrm{D}^{2}$ was significant after reduction. There were two interactions between experimental factors found included $\mathrm{pH}$ with temperature and $\mathrm{pH}$ with time.

The "Lack of Fit F-value" of the reduced model was 0.5482 . This shows that the "Lack of Fit" was not significant relative to the pure error. Thus, it shows that the model gives a good fit with the optimization data and there is a $54.82 \%$ chance that a "Lack of Fit F-value" could occur due to noise. A good fit indicates that the generated model adequately explained the variation of the data and significantly represented the actual relationship between the parameters of the reaction (Taheri et al., 2011). Therefore, it can be concluded that the model gave a good fit.

Table 6 shows the model summary statistics of the reduced model for ACE inhibitory activity. The value of $R$-squared value describes up to what extent a perfect model can be estimated the experimental data points and the adjusted $R$ squared value measured the amount of variation about the mean explained by the model. The "R-squared" value of the model was 0.9675 which is close to 1
(He et al., 2006). Meanwhile, the value of "Predicted R-Squared" of 0.9254 was close to the "Adjusted R-Squared" of 0.9529 . The difference between both values was 0.0275 and acceptable since it was less than 0.2. The "Adeq Precision" value was 26.9214 (Table 6). It was a desirable ratio greater than 4 and indicated an adequate signal. Thereby, this model can be used to navigate the design space in this study.

The final equation in terms of coded factors given by the Design-Expert software is as follows:

ACE inhibitory activity $=+59.94+1.71 * \mathrm{~A}-1.10$ $* \mathrm{~B}+1.10 * \mathrm{C}-1.54 * \mathrm{D}+1.10 * \mathrm{AB}-1.73 * \mathrm{AC}-$ $5.41 * \mathrm{~A}^{2}-13.09 * \mathrm{~B}^{2}+2.35 * \mathrm{D}^{2}$

While the final equation in terms of actual factors is as follows:

ACE inhibitory activity $=-1731.83931+74.19556$ $* \mathrm{~A}+55.71579 * \mathrm{~B}+0.23215 * \mathrm{C}-35.95694 * \mathrm{D}+$ $0.219250 * \mathrm{AB}-0.028792 * \mathrm{AC}-5.40625 * \mathrm{~A}^{2}-$ $0.523450 * \mathrm{~B}^{2}+9.39500 * \mathrm{D}^{2}$

Where A represents $\mathrm{pH}, \mathrm{B}$ represents temperature, $\mathrm{C}$ represents hydrolysis time and $\mathrm{D}$ represents enzyme to substrate ratio $(\mathrm{E} / \mathrm{S})$.

The model equation based on coded factors showed that the most influencing factor was $\mathrm{pH}$, followed by temperature, hydrolysis time, and

Table 6. Summary statistics of the reduced model for ACE inhibitory activity

\begin{tabular}{lrlr}
\hline Std. Dev. & 1.82 & R $^{2}$ & 0.9675 \\
Mean & 50.25 & Adjusted R $^{2}$ & 0.9529 \\
C.V.\% & 3.62 & Predicted R & 0.9254 \\
& & Adeq Precision & 26.9214 \\
\hline
\end{tabular}


enzyme to substrate ratio. This study showed that a quadratic model can be used to explain the relationship between enzymatic protein hydrolysis condition and ACE inhibitory activity for seaweed protein extract.

\section{Response surface plot and effect of independent factors on ACE inhibitory activity}

Four hydrolysis parameters which were $\mathrm{pH}$, temperature, hydrolysis time, and enzyme to substrate ratio were studied during the enzymatic protein hydrolysis of seaweed protein extract using Alcalase ${ }^{\circledR}$. Three-dimensional response surface graphs were generated by the software to explain the interaction of 4 independent variables on $\mathrm{ACE}$ inhibitory activity and to determine the optimum level for each variable to achieve maximum response.

Figure 1 shows the response surface plot of the interaction between $\mathrm{pH}$ and temperature at $120 \mathrm{~min}$ hydrolysis time and $1.75 \%$ enzyme concentration. The hydrolysis time and enzyme to substrate ratio hold at an optimum value respectively. Both temperature and $\mathrm{pH}$ gave a bell-shaped effect to $\mathrm{ACE}$ inhibitory activity. There was a synergistic effect at moderate $\mathrm{pH}$ and moderate temperature, which lead to the maximum ACE inhibitory activity of seaweed protein hydrolysate. There was a lack of study for seaweed that can be used to be compared with the present study. Previous studies that were plantbased protein that had synergic results included cottonseed (Gao et al., 2019) and wheat gluten (Deng et al., 2016) while for animal-based protein were lizardfish (Wu et al., 2012) and angel wing clam (Amiza et al., 2017). The optimum $\mathrm{pH}$ range for Alcalase ${ }^{\circledR}$ to function was between $\mathrm{pH} 6$ to $\mathrm{pH}$ 10 (Aspmo et al., 2005). Moreover, the substrate and enzyme reaction was affected by $\mathrm{pH}$ since $\mathrm{pH}$ altering the distribution and confirmation of the protein molecules. The enzyme tended to lose its stability and undergo irreversible denaturation at very low or high pH (Daniel et al., 1996). ACE inhibitory activity increased with increasing $\mathrm{pH}$ and temperature until the optimum level reached. The ACE inhibitory activity decreased after the optimum condition was reached. The protein structure of the enzyme may denature and altered the proteolytic activity if the hydrolysis condition was carried out at a higher temperature.

Figure 2 shows the response surface plot with the interaction between $\mathrm{pH}$ and hydrolysis time at a temperature of $55^{\circ} \mathrm{C}$ and enzyme to substrate ratio of $1.75 \%$. The graph shows a bell-shaped graph with an optimum level at the highest hydrolysis time and moderate $\mathrm{pH}$. Also, the hydrolysis time gave a linear effect to ACE inhibitory activity. Previous studies that had synergic results included wheat gluten (Deng et al., 2016), winged bean (Mohtar et al.,
2014), and angel wing clam (Amiza et al., 2017). The longer the hydrolysis time, the higher the ACE inhibitory activity by the protein source (Mohtar et al., 2014). Moreover, the ACE inhibitory activity decreased after the optimum $\mathrm{pH}$ level was reached because the enzyme tends to lose its stability at high $\mathrm{pH}$ (Biswanger, 2014).

\section{Optimization of ACE inhibitory activity}

\section{Condition for optimum response}

Table 7 shows the optimization parameters for independent variables and dependent variables. The independent variables which were $\mathrm{pH}$, temperature, hydrolysis time, an enzyme to substrate ratio were set as "in range" whereas the dependent variable which was ACE inhibitory activity was set as "maximize". The ranges for $\mathrm{pH}$, temperature, hydrolysis time, an enzyme to substrate ratio were set from $\mathrm{pH} 6.5$ to $8.5,50^{\circ} \mathrm{C}$ to $60^{\circ} \mathrm{C}, 60$ min to 180 min, and $1.25 \%$ to $2.25 \%$, respectively.

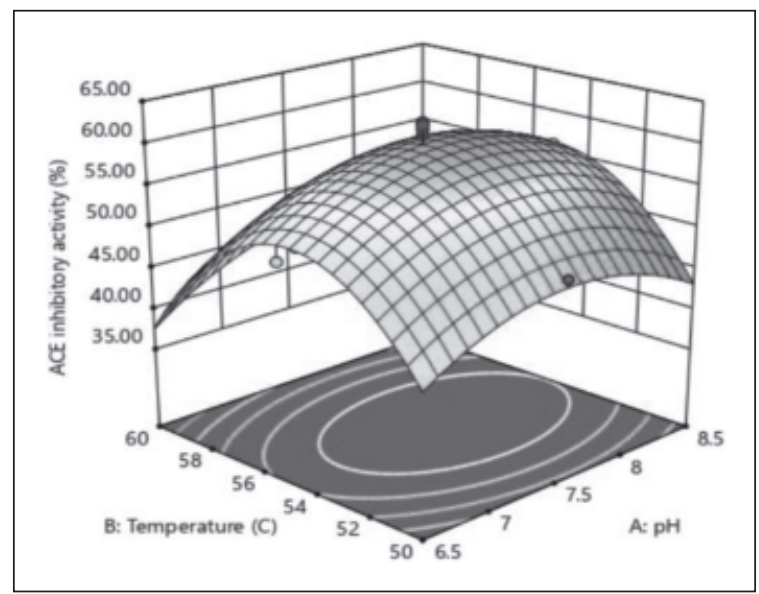

Fig. 1. Response surface graph of enzymatic seaweed protein hydrolysate for ACE inhibitory activity (\%) as a function of $\mathrm{pH}$ and temperature $\left({ }^{\circ} \mathrm{C}\right)$.

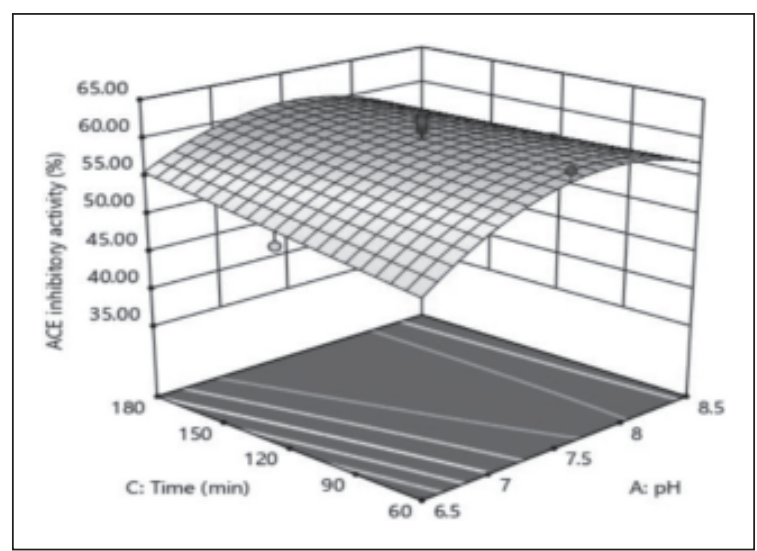

Fig. 2. Response surface graph of enzymatic seaweed protein hydrolysate for ACE inhibitory activity (\%) as a function of $\mathrm{pH}$ and hydrolysis time ( $\mathrm{min})$. 
Table 7. Optimization parameters for independent and dependent variables

\begin{tabular}{|c|c|c|c|c|c|c|}
\hline Name & Goal & $\begin{array}{l}\text { Lower } \\
\text { Limit }\end{array}$ & $\begin{array}{c}\text { Upper } \\
\text { Limit }\end{array}$ & $\begin{array}{l}\text { Lower } \\
\text { Weight }\end{array}$ & $\begin{array}{l}\text { Upper } \\
\text { Weight }\end{array}$ & Importance \\
\hline $\mathrm{A}: \mathrm{pH}$ & is in range & 6.5 & 8.5 & 1 & 1 & 3 \\
\hline B: Temperature & is in range & 50 & 60 & 1 & 1 & 3 \\
\hline C: Time & is in range & 60 & 180 & 1 & 1 & 3 \\
\hline$D: E / S$ & is in range & 1 & 2 & 1 & 1 & 3 \\
\hline ACE inhibitory activity & maximize & 36.425 & 62.5632 & 1 & 1 & 5 \\
\hline
\end{tabular}

Table 8. Selected solutions (only 10 out of 100 solutions) from optimization conditions and maximum responses value

\begin{tabular}{|c|c|c|c|c|c|c|}
\hline Number & $\mathrm{pH}$ & $\begin{array}{l}\text { Temperature } \\
\left({ }^{\circ} \mathrm{C}\right)\end{array}$ & $\begin{array}{l}\text { Time } \\
(\min )\end{array}$ & $\begin{array}{l}E / S \\
(\%)\end{array}$ & $\begin{array}{c}\text { ACE inhibitory activity } \\
(\%)\end{array}$ & Desirability \\
\hline 1 & 7.520 & 54.646 & 175.247 & 1.467 & 62.581 & 1 \\
\hline 2 & 7.766 & 54.409 & 165.074 & 1.378 & 62.841 & 1 \\
\hline 3 & 7.696 & 54.228 & 107.589 & 1.321 & 62.780 & 1 \\
\hline 4 & 7.992 & 54.624 & 94.259 & 1.262 & 63.072 & 1 \\
\hline 5 & 7.781 & 54.742 & 171.724 & 1.352 & 63.231 & 1 \\
\hline 6 & 7.657 & 54.954 & 80.060 & 1.307 & 62.739 & 1 \\
\hline 7 & 7.574 & 55.371 & 124.483 & 1.260 & 63.723 & 1 \\
\hline 8 & 7.500 & 55.000 & 120.000 & 1.250 & 63.826 & 1 \\
\hline 9 & 7.305 & 54.020 & 172.292 & 1.281 & 63.914 & 1 \\
\hline 10 & 7.752 & 54.713 & 153.850 & 1.331 & 63.342 & 1 \\
\hline
\end{tabular}

The degree of importance differs between independent variables and dependent variables. The high number showed the high importance of the variable. The degrees of importance for independent variables were set to 3 while the dependent variable was set to 5. This implied that the ACE inhibitory activity was the most important.

\section{Suggested optimum condition for the response}

Design Expert Version 12 software (Stat Ease Inc.) has generated 100 suggested solutions. The best selection was the solution with the desirability of 1.000. Table 8 shows the solutions of optimization conditions suggested by the software.

Based on Table 8 , the selected suggested condition for this study was solution number 1 with hydrolysis conditions at $\mathrm{pH} \mathrm{7.5,} \mathrm{the} \mathrm{temperature} \mathrm{of}$ $54.6^{\circ} \mathrm{C}$, hydrolysis time of $175 \mathrm{~min}$, and $1.47 \%$ enzyme to substrate ratio. The predicted ACE inhibitory activity was $62.58 \%$ with the desirability of 1.000 .

\section{Verification of optimal conditions for $\mathrm{ACE}$ inhibitory activity}

By using the suggested predicted optimum condition of hydrolysis conditions at $\mathrm{pH} \mathrm{7.5,} \mathrm{the}$ temperature of $54.6^{\circ} \mathrm{C}$, hydrolysis time of $175 \mathrm{~min}$, and $1.47 \%$ enzyme to substrate ratio, four replicates of the seaweed protein extract hydrolysis were prepared. The supernatant of the hydrolysates was lyophilized, before determination of ACE inhibitory activity. The average ACE inhibitory activity obtained in this verification experiment was 61.40 $\pm 0.45 \%$ which was close to the predicted value (62.58) as previously shown in Table 8. Meanwhile, the one-sample t-test showed that there was no significant difference $(p>0.05)$ between the experimental ACE inhibitory activity (61.40 \pm $0.45 \%$ ) and predicted ACE inhibitory activity $(62.58 \%)$ of seaweed protein hydrolysate. Thus, this indicates that the suggested mathematical model can be used to explain the relationship between the experimental independent conditions of seaweed protein extract hydrolysis by Alcalase ${ }^{\circledR}$ towards ACE inhibitory activity.

The optimum condition in the present study was in good agreement with previous studies on whey $\left(\mathrm{pH} 8,45^{\circ} \mathrm{C}, 120 \mathrm{~min}, 2.19 \% \mathrm{E} / \mathrm{S}\right)($ Van der Ven et al., 2002) and rice dreg ( $\mathrm{pH} 8,37^{\circ} \mathrm{C}, 240 \mathrm{~min}, 1.5 \%$ $\mathrm{E} / \mathrm{S}$ ) (He et al., 2005). Previous studies that gave different conditions including Porphyra yezoensis

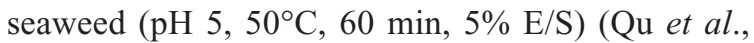
2010) and sour milk (pH 7.5, 39 ${ }^{\circ} \mathrm{C}, 300 \mathrm{~min}, 4 \%$ E/S) (Pan \& Guo, 2010). The reasons for the difference in optimum conditions obtained might be due to the different types of protein sources studied that have different peptide sequences, the different type of enzymes employed during studies 


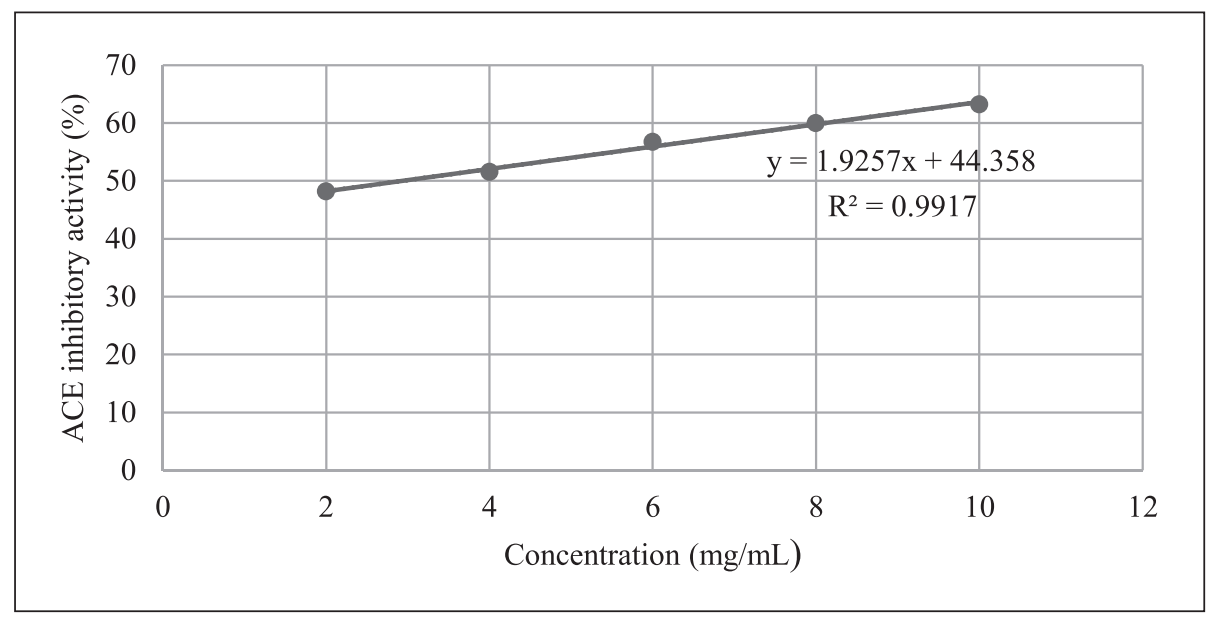

Fig. 3. Half maximal inhibitory concentration $\left(\mathrm{IC}_{50}\right)$ of seaweed protein hydrolysate prepared at optimum condition.

(Daskaya-Dikmen et al., 2017), and the different growing conditions of the plants ( $\operatorname{Rad}$ et al., 2019).

\section{Half maximal inhibitory concentration $\left(\mathrm{IC}_{50}\right)$ of seaweed protein hydrolysate prepared under optimal conditions}

ACE inhibitory activity can be expressed as $\mathrm{IC}_{50}$ value. According to Jeong et al. (2004), $\mathrm{IC}_{50}$ can be defined as the concentration of protein inhibitor required to inhibit $50 \%$ of ACE activity. A lower $\mathrm{IC}_{50}$ value indicates stronger or more potent ACE inhibitory activity (Qu et al., 2010). Figure 3 shows the half-maximal inhibitory concentration $\left(\mathrm{IC}_{50}\right)$ of seaweed protein hydrolysate prepared at optimum condition.

The $\mathrm{IC}_{50}$ of the ACE inhibitory activity of $G$. fisheri protein hydrolysate prepared at optimum condition was $2.97 \pm 0.37 \mathrm{mg} / \mathrm{mL}$. The $\mathrm{IC}_{50}$ of $G$. fisheri was higher compared to other seaweeds such as Dulse (Palmaria palmata) $(0.28$ to $0.78 \mathrm{mg} / \mathrm{mL})$ (Harnedy \& FitzGerald, 2013b), Porphyra yezoensis (1.6 mg/mL) (Qu et al., 2010) and Pyropia columbina (1.2 to $1.7 \mathrm{mg} / \mathrm{mL}$ ) (Cian et al., 2015). Also, the $\mathrm{IC}_{50}$ in this study was higher than the values reported for protein hydrolysate from mushroom (0.31 mg/mL) (Lee et al., 2004), bean (0.04 mg/mL) (Wu \& Ding, 2002), rice bran (0.03 $\mathrm{mg} / \mathrm{mL}$ ) (Wang et al., 2017), peanut $(0.04 \mathrm{mg} / \mathrm{mL})$ (White et al., 2014) and mud crab $(1.96 \mathrm{mg} / \mathrm{mL})$ (Zaliha et al., 2017). However, the $\mathrm{IC}_{50}$ value in the current study was lower than shrimp $(3.37 \mathrm{mg} / \mathrm{mL})$ (Wang et al., 2008) and angel wing clam $(3.29 \mathrm{mg} /$ $\mathrm{mL}$ ) (Amiza et al., 2017). Thus, this study shows that the ACE inhibitory activity of seaweed protein hydrolysate from G. fisheri is lower compared to other seaweeds, but varies in the other sources of protein.
The difference in terms of $\mathrm{IC}_{50}$ value may be due to four reasons. Firstly, the difference in the sequence of peptides of the protein sources. The lower ACE inhibitory activity usually correlates with the lack of the peptides with proline, phenylalanine, and tyrosine at the $\mathrm{C}$-terminus and peptides with valine and isoleucine at the Nterminus (Cheung et al., 1980). Secondly, the pure ACE inhibitory peptides with low molecular weight may yield lower $\mathrm{IC}_{50}$ values than the crude hydrolysate as reported by Cinq-Mars and Li-Chan (2007), whereby the fractionated semi-pure peptides can achieve lower $\mathrm{IC}_{50}$ than unfractionated peptides. Hence, the seaweed protein hydrolysate can undergo purification to obtain a better ACE inhibitory activity. Finally, the different enzymes used in the studies (Cian et al., 2015) and the different conditions of the optimization process (Cian et al., 2015) also may cause variation in $\mathrm{IC}_{50}$ value.

\section{CONCLUSION}

This study shows that the quadratic model can be used to predict the optimum conditions for hydrolysis of seaweed protein extract by using Alcalase ${ }^{\circledR}$ to obtain maximum ACE inhibitory activity. The optimum condition to yield maximum ACE inhibitory activity from Gracilaria fisheri protein extract was $\mathrm{pH} 7.5$, the temperature of $54.6^{\circ} \mathrm{C}$, hydrolysis time of $175 \mathrm{~min}$, and $1.47 \%$ enzyme to substrate ratio. The half-maximal inhibitory concentration $\left(\mathrm{IC}_{50}\right)$ of ACE inhibitory activity from $G$. fisheri protein extract prepared at optimum condition was $2.97 \pm 0.37 \mathrm{mg} / \mathrm{mL}$. Other bioactive peptides such as antioxidant peptides could be further explored from G. fisheri protein extract. 


\section{ACKNOWLEDGEMENT}

The authors acknowledge the financial support from the Ministry of Higher Education Malaysia through the Fundamental Research Grant Scheme (FRGS) (FRGS/1/2018/WAB01/UMT/02/4) to complete this research work.

\section{REFERENCES}

Admassu, H., Gasmalla, M.A.A., Yang, R. \& Zhao, W. 2018. Bioactive peptides derived from seaweed protein and their health benefits: antihypertensive, antioxidant, and antidiabetic properties. Journal of Food Science, 83: 6-16.

Aishah, S., Amiza, M.A., Sarbon, N.M. \& Effendy, W.A.M. 2017. Optimization of enzymatic protein hydrolysis conditions on AngiotensinI-converting enzyme inhibitory (ACEI) activity from blood cockle (Anadara granosa) meat. International Food Research Journal, 24: 565570.

Amiza, M.A., Liyana, H.A. \& Zaliha, H. 2017. Optimization of enzymatic protein hydrolysis conditions to obtain maximum angiotensiniconverting enzyme (ACE) inhibitory activity from Angel Wing Clam (Pholas orientalis) meat. Madridge Journal of Food Technology, 2: 6573.

Amiza, M.A., Nurul Ashikin, S. \& Faazaz, A.L. 2011. Optimization of enzymatic protein hydrolysis from silver catfish (Pangasius sp.) frame. International Food Research Journal, 18: 77578.

AOAC International. 2000. Official methods of analysis of AOAC International. 17th Ed. Washington.

Angell, A.R., Mata, L., de Nys, R. \& Paul, N.A. 2016. The protein content of seaweeds: a universal nitrogen-to protein conversion factor of five. Journal of Applied Phycology, 28: 511-524.

Aspmo, S.I., Horn, S.J. \& Eijsink, V.G.H. 2005. Hydrolysates from Atlantic cod (Gadus morhua $L$.) viscera. as components of microbial growth media. Process Biochemistry, 40: 3714-3722.

Barbarino, E. \& Lourenço, S.O. 2005. An evaluation of methods for extraction and quantification of protein from marine macro- and microalgae. Journal of Applied Phycology, 17: 447-460.

Beaulieu, L., Sirois, M. \& Tamigneaux, É. 2016. Evaluation of the in vitro biological activity of protein hydrolysates of the edible red alga, Palmaria palmata (dulse) harvested from the Gaspe coast and cultivated in tanks. Journal of Applied Phycology, 28: 3101-3115.
Benjama, O. \& Masniyom, P. 2012. Biochemical composition and physicochemical properties of two red seaweeds (Gracilaria fisheri and $G$. tenuistipitata) from the Pattani Bay in Southern Thailand. Songklanakarin Journal of Science and Technology, 34: 223-230.

Biswanger, H. 2014. Enzyme assays. Perspectives in Science, 1: 41-55.

Boonsri, N., Rudtanatip, T., Withyachumnarnkul, B. \& Wongprasert, K. 2016. Protein extract from red seaweed Gracilaria fisheri prevents acute hepatopancreatic necrosis disease (AHPND) infection in shrimp. Journal of Applied Phycology, 29: 1597-1608.

Briggs, M.R.P. \& Smith, S.J.F. 1993. Macroalgae in aquaculture: An overview and their possible roles in shrimp culture, in: Proceedings of the Conference on Marine Biotechnology in the Asia Pacific, pp. 137-143.

Chan, P.T. \& Matanjun, P. 2017. Chemical composition and physicochemical properties of tropical red seaweed, Gracilaria changii. Food Chemistry, 221: 302-310.

Cheung, H., Wang, F. \& Ondetti, M.A. 1980. Binding of peptide substrates and inhibitors of angiotensin-converting enzyme. Journal of Biological Chemistry, 255: 401-407.

Cian, R.E., Garzón, A.G., Ancona, D.B., Guerrero, L.C. \& Drago, S.R. 2015. Hydrolyzates from Pyropia columbina seaweed have antiplatelet aggregation, antioxidant and ACE I inhibitory peptides which maintain bioactivity after simulated gastrointestinal digestion. Food Science and Technology, 64: 881-888.

Cinq-Mars, C.D. \& Li-Chan, E.C. 2007. Optimizing angiotensin i-converting enzyme inhibitory activity of pacific hake (Merluccius productus) fillet hydrolysate using response surface methodology and ultrafiltration. Journal of Agricultural and Food Chemistry, 55: 93809388.

Cushman, D.W. \& Cheung, H.S. 1971. Spectrophotometric assay and properties of the angiotensin-converting enzyme of rabbit lung. Biochemical Pharmacology, 20(7): 1637-1648.

Dadzie, R.G., Ma, H., Abano, E.E., Qu, W. \& Mao, S. 2013. Optimization of process conditions for production of angiotensin I-converting enzyme (ACE) inhibitory peptides from vital wheat gluten using response surface methodology. Food Science and Biotechnology, 22: 15311537.

Daniel, R.M., Dines, M. \& Petach, H.H. 1996. The denaturation and degradation of stable enzymes at high temperatures. Biochemical Journal, $\mathbf{3 1 7}$ : $1-11$. 
Daskaya-dikmen, C., Yucetepe, A., Karbanciogluguler, F. \& Daskaya, H. 2017. Angiotensin-iconverting enzyme (ACE)-inhibitory peptides from plants. Nutrients, 9: 1-19.

Deng, L., Wang, Z., Yang, S., Song, J., Que, F., Zhang, H. \& Feng, F. 2016. Improvement of functional properties of wheat gluten using acid protease from Aspergillus usamii. PLoS ONE, 11: e0160101.

FAO. 2016. The State of World Fisheries and Aquaculture.

Fleurence, J. 1999. Seaweed proteins: biochemical, nutritional aspects and potential uses. Trends in Food Science and Technology, 10: 25-28.

Fleurence, J., Massiani, L., Guyader, O. \& Mabeau, S. 1995. Use of enzymatic cell wall degradation for improvement of protein extraction from Chondrus crispus, Gracilaria verrucosa and Pabmaria palmata. Journal of Applied Phycology, 7: 393-397.

Galland-Irmouli, A.V., Fleurence, J., Lamghari, R., Luçon, M., Rouxel, C., Barbaroux, O., Bronowicki, O., Jean, P., Villaume, C. \& Guéant, J.L. 1999. Nutritional value of proteins from edible seaweed Palmaria palmata (Dulse). Journal of Nutritional Biochemistry, 10: 353359.

Gao, D., Zhang, F., Ma, Z., Chen, S., Ding, G., Tian, X. \& Feng, R. 2019. Isolation and identification of the angiotensin-I converting enzyme (ACE) inhibitory peptides derived from cottonseed protein: optimization of hydrolysis conditions. International Journal of Food Properties, 22: 1296-1309.

Guang, C. \& Phillips, R.D. 2009. Plant food-derived angiotensin i converting enzyme inhibitory peptides. Journal of Agricultural and Food Chemistry, 57: 5113-5120.

Guo, Y., Pan, D. \& Tanokura, M. 2009. Optimisation of hydrolysis conditions for the production of the angiotensin-I converting enzyme (ACE) inhibitory peptides from whey protein using response surface methodology. Food Chemistry, 114: 328-333.

Gupta, S., Kapoor, P., Chaudhary, K., Gautam, A., Kumar, R. \& Raghava, R.P.S. 2013. In silico approach for predicting toxicity of peptides and proteins. PLoS One, 8(9): e73957.

Hamilton, D.F., Ghert, M. \& Simpson, A.H.R.W. 2015. Interpreting regression models in clinical outcome studies. Bone and Joint Research, 4: 152-153.

Harnedy, P.A. \& FitzGerald, R.J. 2013a. Extraction of protein from the macroalga Palmaria palmata. Food Science and Technology, 51: 375-382.
Harnedy, P.A. \& FitzGerald, R.J. 2013b. In vitro assessment of the cardioprotective, anti-diabetic and antioxidant potential of Palmaria palmata protein hydrolysates. Journal of Applied Phycology, 25: 1793-1803.

Harrysson, H., Hayes, M., Eimer, F., Carlsson, N.G., Toth, G.B. \& Undeland, I. 2018. Production of protein extracts from Swedish red, green and brown seaweeds, Porphyra umbilicalis Kützing, Ulva lactuca Linnaeus and Saccharina latissima (Linnaeus) using three different methods. Journal of Applied Phycology, 30: 3565-3580.

Hayes, M. 2018. Food proteins and bioactive peptides: New and novel sources, characterisation strategies and applications. Foods, 7: 38.

He, G., Xuan, G., Ruan, H., Chen, Q. \& Xu, Y. 2005. Optimization of angiotensin-I-converting enzyme (ACE) inhibition by rice dregs hydrolysates using response surface methodology. Journal of Zhejiang University Science, 6B: $508-513$.

Imjongjairak, S., Ratanakhanokchai, K., Laohakunjit, N., Tachaapaikoon, C., Pason, P. \& Waeonukul, R. 2015. Biochemical characteristics and antioxidant activity of crude and purified sulfated polysaccharides from Gracilaria fisheri. Bioscience, Biotechnology and Biochemistry, 80: $524-532$.

Iwaniak, A., Minkiewicz, P. \& Darewicz, M. 2014. Food-originating ACE inhibitors, including antihypertensive peptides, as preventive food components in blood pressure reduction. Comprehensive Reviews in Food Science and Food Safety, 13: 114-134.

Jeong, S., Chung, K. \& Lee, J. 2004. Characterization of antihypertensive angiotensin i-converting enzyme inhibitor from Saccharomyces cerevisiae. Journal of Microbiology and Biotechnology, 14: 1318-1323.

Kadam, S.U., Álvarez, C., Tiwari, B.K. \& O’Donnell, C.P. 2017. Extraction and characterization of protein from Irish brown seaweed Ascophyllum nodosum. Food Research International, 99: 1021-1027.

Kim, S.Y., Je, J.Y. \& Kim, S.K. 2007. Purification and characterization of antioxidant peptide from hoki (Johnius belengerii) frame protein by gastrointestinal digestion. Journal of Nutritional Biochemistry, 18: 31-38.

Kim, S. \& Wijesekara, I. 2010. Development and biological activities of marine-derived bioactive peptides/: A review. Journal of Functional Foods, 2:1-9.

Kitts, D.D. \& Weiler, K. 2003. Bioactive proteins and peptides from food sources. Applications of bioprocesses used in isolation and recovery. Current Pharmaceutical Design, 9: 1309-1323. 
Kjeldsen, S.E. 2018. Hypertension and cardiovascular risk: General aspects. Pharmacological Research, 129: 95-99.

Ko, S.C., Kang, N., Kim, E.A., Kang, M.C., Lee, S.H., Kang, S.M., Lee, J.B., Jeon, B.T., Kim, S.K., Park, S.J., Park, P.J., Jung, W.K., Kim, D. \& Jeon, Y.J. 2012a. A novel angiotensin I-converting enzyme (ACE) inhibitory peptide from a marine Chlorella ellipsoidea and its antihypertensive effect in spontaneously hypertensive rats. Process Biochemistry, 47: 2005-2011.

Ko, S.C., Lee, J.K., Byun, H.G., Lee, S.C. \& Jeon, Y.J. 2012 b. Purification and characterization of angiotensin I-converting enzyme inhibitory peptide from enzymatic hydrolysates of Styela clava flesh tissue. Process Biochemistry, 47: 3440.

Kristinsson, H.G. \& Rasco, B.A. 2000. Fish protein hydrolysates: Production, biochemical and functional properties. Critical Reviews in Food Science and Nutrition, 40: 43-81.

Laohakunjit, N., Selamassakul, O. \& Kerdchoechuen, O. 2014. Seafood-like flavour obtained from the enzymatic hydrolysis of the protein by-products of seaweed (Gracilaria sp.). Food Chemistry, 158: $162-170$.

Larson, M.G. 2008. Analysis of Variance. Circulation, 117: 115-121.

Lawanyawut, K., Warotaipan, S. \& Kaewkong, A. 2002. Nutritional composition and $\mathrm{Ca}, \mathrm{P}$ and Fe quantities of seaweed in Thailand. Fisheries Science, 68(sup2): 1321-1322.

Lee, D.H., Kim, J.H., Park, J.S, Choi, Y.J. \& Lee, J.S. 2004. Isolation and characterization of a novel angiotensin I-converting enzyme inhibitory peptide derived from the edible mushroom Tricholoma giganteum. Peptides, 25: 621-627.

Lee, S.H., Qian, Z.J. \& Kim, S.K. 2010. A novel angiotensin-I-converting enzyme inhibitory peptide from tuna frame protein hydrolysate and its antihypertensive effect in spontaneously hypertensive rats. Food Chemistry, 118: 96-102.

Messerli, F.H. 2002. Vasodilatory edema: A common side effect of antihypertensive therapy. Current Cardiology Reports, 4: 479-482.

Mishra, V.K., Temelli, F., Ooraikul, B., Shacklock, P.F. \& Craigie, J.S. 1993. Lipids of the red alga, Palmaria palmata. Botanica Marina, 36(2): 169-174.

Mohtar, W.A.A., Hamid, A.A., Abd-Aziz, S., Muhamad, S.K.S. \& Saari, N. 2014. Preparation of bioactive peptides with high angiotensin converting enzyme inhibitory activity from winged bean (Psophocarpus tetragonolobus (L.) DC.) seed. Journal of Food Science and Technology, 51: 3658-3668.
Montgomery, D. 2001. Experimental Designs for Fitting Response Surfaces. In Design and analysis of experiments. 5th Ed. Wiley, New York. 455 pp.

Morshedi, A. \& Akbarian, M. 2014. Application of response surface methodology: design of experiments and optimization: A mini review. Indian Journal of Fundamental and Applied Life Sciences, 4: 2434-2439.

Nedjar-Arroume, N., Barkia, A., Guillochon, D., Nasri, M., Leroy, Y., Bougatef, A. \& RavallecPlé, R. 2008. Angiotensin I-converting enzyme (ACE) inhibitory activities of sardinelle (Sardinella aurita) by-products protein hydrolysates obtained by treatment with microbial and visceral fish serine proteases. Food Chemistry, 111: 350-356.

Nguyen, P.T., Ruangchuay, R. \& Lueangthuwapranit, C. 2018. Patterns of Element Concentrations and Heavy Metal Accumulations in Edible Seaweed, Gracilaria fisheri (Xia and Abbott) Abbott, Zhang and Xia (Gracilariales, Rhodophyta) Cultivation in Southern Thailand. Journal of Fisheries and Environment, 42(3): 13-25.

Normah, I., Jamilah, B., Saari, N. \& Che Man Yaakob, B. 2005. Optimization of hydrolysis conditions for the production of threadfin bream (Nemipterus japonicus) hydrolysate by Alcalase. Journal of Muscle Foods, 16(2): 87-102.

Paiva, L., Lima, E., Neto, A.I. \& Baptista, J. 2017. Angiotensin I-converting enzyme (ACE) inhibitory and amino acid profiles of Fucus spiralis L. protein. Marine Drugs, 15: 1-18.

Paiva, L., Lima, E., Neto, A.I. \& Baptista, J. 2016. Isolation and characterization of angiotensin I-converting enzyme (ACE) inhibitory peptides from Ulva rigida $C$. Agardh protein hydrolysate. Journal of Functional Foods, 26: 65-76.

Palmer, P.B. \& Connell, D.G. 2009. Regression Analysis for Prediction: Understanding the Process. Cardiopulmonary Physical Therapy Journal, 20: 23-26.

Pan, D. \& Guo, Y. 2010. Optimization of sour milk fermentation for the production of ACEinhibitory peptides and purification of a novel peptide from whey protein hydrolysate. International Dairy Journal, 20: 472-479.

Qu, W., Ma, H., Pan, Z., Luo, L., Wang, Z. \& He, R. 2010. Preparation and antihypertensive activity of peptides from Porphyra yezoensis. Food Chemistry, 123: 14-20.

Rad, S.Z.K., Javadi, B., Hayes, A.W. \& Karimi, G. 2019. Potential angiotensin converting enzyme (ACE) inhibitors from Iranian traditional plants described by Avicenna's Canon of Medicine. Avicenna Journal of Phytomedicine, 9: 291. 
Rodan, K., Fields, K. \& Falla, T. 2017. Bioactive peptides. Foods, 6: 1-2.

Rodrigues, C.F.S., Lima, F.J.C. \& Barbosa, F.T. 2017. Importance of using basic statistics adequately in clinical research. Brazilian Journal of Anesthesiology (English Edition), 67: 619-625.

Rohani-Ghadikolaei, K., Abdulalian, E. \& Ng, W.K. 2012. Evaluation of the proximate, fatty acid and mineral composition of representative green, brown and red seaweeds from the Persian Gulf of Iran as potential food and feed resources. Journal of Food Science and Technology, 49: 774-780.

Rutherfurd-Markwick, K.J. 2012. Food proteins as a source of bioactive peptides with diverse functions. British Journal of Nutrition, 108: S149-S157.

Sánchez, A. \& Vázquez, A. 2017. Bioactive peptides: A review. Food Quality and Safety, 1: 29-46.

Seca, A.M.L. 2018. Overview on the antihypertensive and anti-obesity effects of secondary metabolites from seaweeds. Marine Drugs, 237: 1-17.

Setthamongkol, P., Tunkijjanukij, S., Satapornvanit, K. \& Slaenoi, J. 2015. Growth and nutrients analysis in marine macroalgae. Kasetsart Journal Natural Science, 49(2): 211-218.

Shanley, A. 2018. Sartan recalls beg the question: Is compendial impurity testing enough? Pharmaceutical Technology, 42: 60-63.

Sun, S., Xu, X., Sun, X., Zhang, X., Chen, X. \& Xu, N. 2019. Preparation and Identification of ACE Inhibitory Peptides from the Marine Macroalga Ulva Intestinalis. Marine Drugs, 17: 179.

Uluko, H., Zhang, S., Liu, L., Chen, J., Sun, Y., Su, Y., Li, H., Cui, W. \& Lv, J. 2013. Effects of microwave and ultrasound pretreatments on enzymolysis of milk protein concentrate with different enzymes. International Journal of Food Science and Technology, 48: 1-8.

Van der Ven, C., Gruppen, H., De Bont, D.B.A. \& Voragen, A.G.J. 2002. Optimisation of the angiotensin converting enzyme inhibition by whey protein hydrolysates using response surface methodology. International Dairy Journal, 12: 813-820.

Venugopal, V. 2009. Functional and bioactive nutraceutical compounds from the ocean. Marine product for healthcare. London, CRC Press. 527 pp.

Venugopal, V. 2008. Marine products for healthcare: functional and bioactive nutraceutical compounds from the ocean. London, CRC Press. $263 \mathrm{pp}$.
Vijaykrishnaraj, M. \& Prabhasankar, P. 2015. Marine protein hydrolysates: Their present and future perspectives in food chemistry - A review. Royal Society of Chemistry Advances, 5: 3486434877.

Voet, D., Voet, J.G. \& Pratt, C.W. 2018. Voet's Principles of Biochemistry. 5th Edition. Global Edition. John Wiley \& Sons Inc, UK.

Wang, X., Chen, H., Fu, X., Li, S. \& Wei, J. 2017. A novel antioxidant and ACE inhibitory peptide from rice bran protein: Biochemical characterization and molecular docking study. Food Science and Technology, 75: 93-99.

White, B.L., Sanders, T.H. \& Davis, J.P. 2014. Potential ACE-inhibitory activity and nanoLCMS/MS sequencing of peptides derived from aflatoxin contaminated peanut meal. Food Science and Technology, 56: 537-542.

Wijesekara, I. \& Kim, S. 2010. Angiotensin-Iconverting enzyme (ACE) inhibitors from marine resources: Prospects in the pharmaceutical industry. Marine Drugs, 8: 1080-1093.

Wijesinghe, W.A. \& Jeon, Y.J. 2012. Enzymeassistant extraction (EAE) of bioactive components: A useful approach for recovery of industrially important metabolites from seaweeds: A review. Fitoterapia, 83: 6-12.

Wu, J. \& Ding, X. 2002. Characterization of inhibition and stability of soy-protein-derived angiotensin I-converting enzyme inhibitory peptides. Food Research International, 35: 367375.

Wu, S., Sun, J., Tong, Z., Lan, X., Zhao, Z. \& Liao, D. 2012. Optimization of hydrolysis conditions for the production of angiotensin-i converting enzyme-inhibitory peptides and isolation of a novel peptide from lizard fish (Saurida elongata) muscle protein hydrolysate. Marine Drugs, 10: 1066-1080.

Yokoyama, K., Chiba, H. \& Yoshikawa, M. 2009. Peptide inhibitors for angiotensin i-converting enzyme from thermolysin digest of dried bonito. Bioscience, Biotechnology and Biochemistry, 56: 1541-1545.

Zaliha, H., Amiza, M.A., Sarbon, N.M. \& Khairi, M. 2017. Optimisation of enzymatic protein hydrolysis of mud crab (Scylla sp.) to obtain maximum angiotensin-I-converting enzyme (ACE) inhibitory activity using response surface methodology. Malaysian Applied Biology Journal, 46: 33-40. 
